\title{
Fuzzy TOPSIS Method as a Decision Supporting System to Rank Malaysia Online Shopping Website Quality During COVID-19 MCO 2020
}

\author{
Soo-Fen Fam ${ }^{1}$, Joshua Huang ${ }^{2}$, Zun Liang Chuan ${ }^{3}$, Siti Nurhaida Khalil ${ }^{4}$, Dedy Dwi Prastyo ${ }^{5}$, \\ Fatin Najwa Mohd Nusa ${ }^{6}$ \\ ${ }^{1,2,4}$ Faculty of Technology Management and Technopreneurship, Universiti Teknikal Malaysia Melaka, Malaysia \\ ${ }^{3}$ Faculty of Industrial Sciences and Technology, Universiti Malaysia Pahang \\ ${ }^{5}$ Institut Teknologi Sepuluh Nopember, Kampus ITS-Sukolilo, Surabaya, Indonesia \\ ${ }^{6}$ Malaysia Institute of Transport (MITRANS), Univerisiti Teknologi MARA (UiTM), Selangor, Malaysia \\ ${ }^{1}$ famsoofen@utem.edu.my
}

\begin{abstract}
The rapid growth of Internet technology development has allowed consumers to purchase online products or services, especially during the Movement Control Order (MCO) lockdown due to the COVID-19 pandemic in Malaysia. Online shopping has become a new norm; however, the services needed frequent updates for improvements. Literature has shown that online shopping website quality influenced online shoppers' decision-making. Hencein improving the quality of online shopping websites, the criteria for the website's quality is vital. Therefore, this study aims to identify the criteria of Malaysia online shopping website quality and rank the website quality by using Fuzzy TOPSIS method. Questionnaire is developed for website usersto evaluate the online shopping website quality via google form and disseminated through social media. After data cleaning, 300 respondents' data were used for analysis. The result shows that the online shopping website quality for Shopee is ranked the first, next is Lazada, then Lelong and finally the 11 -street.
\end{abstract}

Key words: Fuzzy TOPSIS, COVID-19, Decision Support, MCDM, MCO, Online Shopping Website, Website Quality

\section{INTRODUCTION}

The rapid growth of the Internet of Things (IoT) technology has allowed consumers to purchase online retailers' products or services. Especially during the Movement Control Order (MCO) due to COVID-19 virus pandemic in Malaysia, online shopping has become a critical business platform for both consumers and traders alike [1]. Shopping online offers customers more advantages as they can save their precious time, cashless transaction most importantly, it helps in preventing the spreading of the virus due to minimal human to human contact. Also, online shopping platform allows customers to find most of the things that they want under one roof [2].
On the other hand, in the new era of integration of digital marketing and green economy for sustainable development, the business can place less reliance on brick and mortar stores. Sellers and buyers can leverage burgeoning e-commerce platforms. Hence, online shopping has increasing become a preference for both sellers and buyers. [3] has reported that the e-commerce revenues during MCO lockdown are 40 per cent higher than pre-pandemic revenues.

According to National E-commerce Strategic Roadmap (2018), online business in Malaysia is developing at over $10 \%$ every year. This growth doubles to $20.8 \%$ in the year 2020 . Nowadays, the online business commitment to Malaysia GDP is at $5.9 \%$ and anticipated to be $6.4 \%$ in the year 2020 with an engaged government intercession. Moreover, an online business can help organizations to fabricate better abilities, support efficiency and extend pieces of the overall industry. Online business has contributed significantly to the nation's economy over the years, as shown in Figure 1.

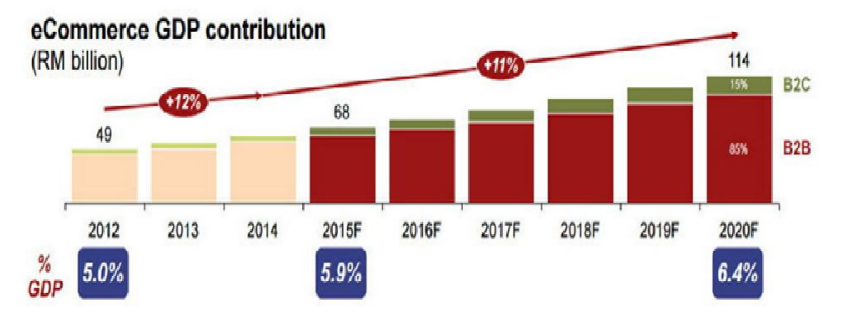

Figure 1: Malaysia E-commerce GDP Contribution Sources: National E-commerce Strategic Roadmap

Online shopping website acts as a powerful medium between the seller and consumer [4] immensely when Covid-19 pandemic had sped up the digital transformation. Consumers are always looking for quality and reliable online shopping website to do online shopping [5]. Poorly designed websites can influence the users and result in a high "bounce rate", or users go the entrance page without browsing other pages on the site [6]. On the other hand, a well-designed, easily functional website positive impact on user retention.

The objective of this research is to evaluate the four most favourite online shopping website quality in Malaysia during 
Soo-Fen Fam et al., International Journal of Emerging Trends in Engineering Research, 8(9), September 2020, 6397 - 6405

the Covid-19 MOC period. However, there are some shortcomings in the current calculation on the online shopping website quality. According to [7], efficiency measurements of the online shopping platform ignore standards for measuring online website caused inadequate information to capture consumers' frustration and the reasons consumers turn to others online shopping The reasons consumers turn to other online shopping websites is in question; thus this research proposes to Multi-Criteria Decision Making-(MCDM)-fuzzy Technique for Order Performance by Similarity to Ideal Solution (TOPSIS) method to rank the Malaysia online shopping website quality. Up to the knowledge of authors, there is the pioneer study on rating Malaysia online shopping website by using fuzzy TOPSIS method during the MCO lockdown period in year 2020.

Findings from this study will portray an insight from the perspective of Malaysian online users. The results anticipate reviving e-commerce online shopping provider in addressing the competition issues and improve the website quality. Online stores and online shopper also can use these findings for their references.

The remainder of this paper is as follows: Section 2 literature review on the Fuzzy TOPSIS online shopping website quality, criteria, sub-criteria and alternatives. Section 3 presents the methodology: Section 4 analysis and results and the last section is the conclusion and future research direction.

\section{LITERATURE REVIEW}

\subsection{Fuzzy TOPSIS}

Fuzzy set theory has been used to model structures which are difficult to precisely describe. It integrates the imprecise and subjective essence of human decision-making into the process of model formulation and solution [8]. Since Zadeh first proposed fuzzy set theory and Bellman and Zadeh defined the decision-making approach in fuzzy environments, by applying fuzzy set theory a growing number of studies have addressed uncertain fuzzy problems [9]. The fuzzy TOPSIS approach can handle the fluidity of the data involved in decision making in an efficient way. The fuzzy logic and results of the fuzzy approach are better than conventional statistical approach because of the ability of different evaluators to catch difference and uncertainty in terms of linguistic variables, which are particularly relevant in assessing of the website quality.

Fuzzy TOPSI method has been carried out for various of studies but very scarce in evaluating online shopping website. [10], have used fuzzy TOPSIS together with regression-based weights to rank E-commerce websites in Turkey. The study discovered, different method and senses of criteria weighting produced different ranking results. [11]also used the Intuitionist Fuzzy TOPSIS tool to studyonline customer satisfaction level of grocery e-retailers in India to achieve their goal to establish in the market. Similarly [12] applied fuzzy TOPSIS method to evaluate five Turkish bookstores website quality. Four main categories together with fifteen sub-criteria were used in assessing the quality of the bookstores' websites. This research, authors have adapt [12] framework to evaluate Malaysia online shopping website quality in Malaysia.

In order to carry out Fuzzy TOPSIS analysis in this research, determination of the criteria and alternatives to fit in the Fuzzy decision matrix wereperquisites. Subsequently, section 2.2 will perform the literature review for criteria and sub criteria for the online shopping website quality and Section 2.3 is the review for the online shopping website alternatives.

\subsection{Online Shopping Website Quality}

The consistency of the online shopping website is very critical for both increased sales and customer satisfaction [12]. The website plays an important essential role in supporting transactions between consumers and businesses in an online shopping world [13]. Many online shopping websites, as we can see, attract more customers than others simply because of excellent website design features, a secure structure, or easy interface [14]. Online shopping Website efficiency is therefore, therefore, a key critical factor in the business success of online shopping sellers [15].

Online shopping website quality is a multi-dimensional structure, according to previous research [16], representing the general quality of the website of online vendors [17]. It is generally recognized that quality of the website requires information quality, quality of service and quantity of the system [18]; [13].

Information quality refers to the quality of web content [18]; [19] and contributes to the extent of importance, timeliness, personalization, and accuracy of the website content [20]; [21]). Higher quality website information makes it easier for customers to make a quick buying decision, allowing the website highly appealing to consumers than other websites [22].

Quality of service reflects the extent to which customers judge the overall services benefits and support offered by the website [23],[17],[22]. This encompasses durability, reliability, and sensitivity [18].. For shopping websites, service quality is important essential as there is no face-to-face interaction in an online shopping world [23].

System quality is characterized as the purchaser-perceived output of a website system [24],[17]. System quality This includes some of the system's key essential features, such as navigation, access speed, user-friendliness, and aesthetic appeal [25]. High-system shopping websites can provide consumers with an enjoyable online shopping experience, which in turn affects shoppers ' attitudes and behaviours [13].

According to the study [26], user understanding of website quality is focused on the functionality of a website that meets consumer needs and impresses the website's overall excellence. The study's authors also stated that website quality can be categorized as protection, enjoyment, availability of information, simplicity of use, service quality. In addition also, website design is an important essential indicator of website functionality and is essential critical to achieving the 
Soo-Fen Fam et al., International Journal of Emerging Trends in Engineering Research, 8(9), September 2020, 6397 - 6405

level of service provided by the website to customers [27]. Aesthetic appearance, navigation and a structured and well-managed presentation of content are key features of good website design [28].

Within e-commerce websites, attractive and interesting exciting results inspire customers to participate within online shopping practices [29]. Website features, according to community researchers [30], have a significant influence on the intention of buying online consumers. Therefore, the quality of information that the online website offers is also important crucial for assessing the quality of the website. The highest effect on customer satisfaction among all website content measurements is one of the specific studies that shows the knowledge quality [31].

High High-quality customer service is a way to enhance the aggressiveness of a company. The Internet gives smart business applications a dynamic and disseminated level. A growing need, however, is to build a system for identifying prevalent principal components. Web-based quality of service, assessing customer satisfaction online, and achieving a high quality of service [32] are part of critical consumer service. The required contribution program has become a focal issue as organizations have slowly begun to interact and link digitally with buyers. Attracting and maintaining customers requires a thorough understanding of users ' needs and effective practical solutions tailoring $[33,34]$.

While internet shopping gradually transitions from novelty to regular shopping, online websites efficiency should play a significant role in distinguishing websites. In order to attracting customers and influence their buying decisions, the quality of online shopping websites should be of be of high extremely high quality [35]. There is evidence that website-based service quality is a critical success strategy, probably more important than a low price and web presence [36].

However, a high-quality website not just to defines the decision of the consumer to buy, but also becomes a major significant reason for whether or not a customer can buy online [37]. The authors state that websites of low quality could lead to loss of customers, cost inflation and reduction of income. Therefore, it is important vital to understand the quality of the website in buying decisions that affect consumer trust on the websites. Consumer experience quality is in parallel with will be influenced by website quality components such as information quality, service quality, and system quality. Customers will continue to have greater confidence in the seller with the web site's high quality than after customers use it.

The research framework generated by the three main criteria with the ten sub-criteria respectively, is shown in Figure 2. Service quality, system quality and information quality are the main criteria which have been labeled as $\mathrm{C}_{1}, \mathrm{C}_{2}$ and $\mathrm{C}_{3}$ respectively in fuzzy decision metrix. The alternatives are presented in the following subsection 2.3.

\subsection{Four Most Favorite Malaysia Online Shopping Website}

Four most favourite Malaysia online shopping website, namely Lazada, Shopee, 11-street and Lelong, and are selected in evaluating their website quality via public opinions.

Lazada is an app-based service that allows sellers to tap advanced technologies into their network and expand their business on the go. It is a private business that was founded in

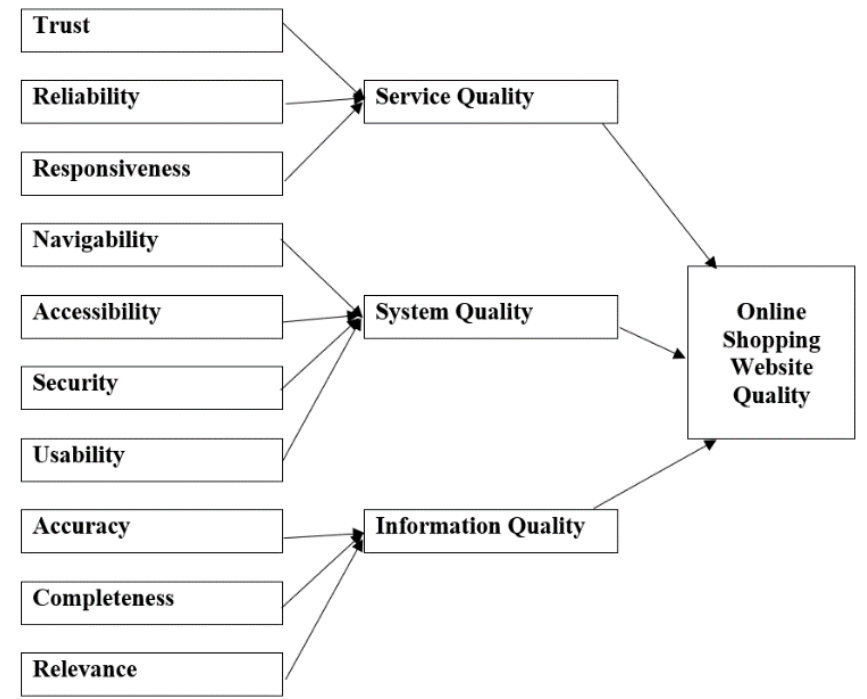

Figure 2: Main criteria and sub-criteria used in measuring Malaysia Online Shopping Website Quality

2012 and currently operates below the Alibaba Group Ltd. Lazada has a complex model of the industry that can fit third-party retailers. It ranks as the leading e-commerce site in Southeast Asia based on the average monthly visits, with the Malaysian branch at the top of the list. Lazada has over 15 million customer base and is a platform for more than 35,000 sellers.

Shopee was established in 2015 as a multi-lingual e-commerce website. The company, based in Singapore, operates under the Sea Group Ltd., a billion-dollar corporation. As of 2017, it has become Malaysia's third most visited e-commerce website. In addition, it ranked in 2015 as the Best Startup of the Year. According to Digital News Asia (2019), Shopee was the largest Shopping App with Monthly Active Users, mostly downloads, and the most visited websites, ahead of Lazada's rivals.

11-street is an online retail store that provides retailers with a marketplace where they can market their products digitally. Malaysia's 11-street is establishing in 2014, which is a joint venture between Malaysia's mobile telecommunications company Celcom Axiata and SK Planet, founder of the original 11-street platform in South Korea.

Lelong is a local king released in 1998. Although it only operates in Malaysia, Lelong welcomes foreign sellers, whether individual or business. It is a consumer-friendly website that provides multi-variant styles to sellers for fuss-free setup. Lelong still manages to record an average of 8 million frequent visits, though a local forum. It is now home 
Soo-Fen Fam et al., International Journal of Emerging Trends in Engineering Research, 8(9), September 2020, 6397 - 6405

to more than 8,000 profitable stores, ranging from one-man-show companies to big businesses.

In this study, Lazada is assigned as alternative $1\left(\mathrm{~A}_{1}\right)$, Shopee as alternative $2\left(\mathrm{~A}_{2}\right)$, 11-street as alternative $3\left(\mathrm{~A}_{3}\right)$ and Lelong as alternative $\left(\mathrm{A}_{4}\right)$ to be input in the fuzzy decision matrix.

\section{METHODOLOGY}

\subsection{Data Collection}

This research aims to rank the four most favourite online shopping website quality in Malaysia. Questionnaires are designed accordingly to evaluate them effectively and the efficiency of the online website. A google form with 5 points Liker scales were developed with two sections namely section A and section B. Section A is about respondents' demographic profiles and online shopping behaviour. While section B is about respondents' comments on the quality of the Malaysia online shopping website.

The total Malaysia population is estimated at $31,949,777$ people at mid-year 2019, referring to UN data (2019). According to [38] table, 384 respondents is needed as a sample size in this research.

Due to MCO lockdown, data collection is carried out via electronic methods. The targeted respondents are those who used social media such as Facebook, WhatsApp, email, telegrams, WeChat and Twitter for communication. In addition, they also must have experienced the Malaysia online shopping website experiences. Data collection is carried out through three stages which are pre-test, pilot and field study.

\subsection{Conversion linguistic to fuzzy set}

Conversion scales are used to turn linguistic words into numbers that are fuzzy. Usually, apply a scale of 1 to 9 when the parameters and alternatives are evaluated. For the fuzzy triangular numbers used for the five linguistic ratings, the intervals are selected to have a uniform representation from 1 to 9 refer to Table 1 .

Table 1: Conversion Likert scale in questionnaire to fuzzy set

\begin{tabular}{|l|l|l|}
\hline $\begin{array}{l}\text { 5-point } \\
\text { Likert Scale }\end{array}$ & $\begin{array}{l}\text { Assessment based on } \\
\text { 5-point Likert Scale }\end{array}$ & Fuzzy Number \\
\hline 1 & Very Poor (VP) & $(1,1,3)$ \\
\hline 2 & Poor (P) & $(1,3,5)$ \\
\hline 3 & Fair (F) & $(3,5,7)$ \\
\hline 4 & Good (G) & $(5,7,9)$ \\
\hline 5 & Very Good (VG) & $(7,9,9)$ \\
\hline
\end{tabular}

\subsection{Rating:Fuzzy TOPSIS method}

The TOPSIS method is used to test various alternatives against the criterion chosen. An alternative nearest to the Fuzzy Positive Ideal Solution (FPIS) and farthest from the Fuzzy Negative Ideal Solution (FNIS) is selected as optimal in the TOPSIS approach. For the alternative, an FPIS consists of the best performance values, while the FNIS is the worst results. Step by step of the Fuzzy Topsis method are following [12]:
Step 1: Fuzzy aggregate computing for criteria and alternatives

Suppose there are $m$ possible alternatives called $A=\left\{A_{1}, A_{2}\right.$, ..., $\left.\mathrm{A}_{\mathrm{m}}\right\}$ to be tested against $n$ requirements, $\mathrm{C}=\left\{\mathrm{C}_{1}, \mathrm{C}_{2}, \ldots\right.$, $\left.\mathrm{C}_{\mathrm{n}}\right\}$. The weights of the parameters are indicated by wi, $i=1$, $2, \ldots, n$.

Suppose a decision group has $\mathrm{K}$ individuals, then the ranking of alternatives can be determined as below with respect to each criterion.

$$
\tilde{x}_{i j}=\frac{1}{K}\left[\tilde{x}_{i j}^{1}+\tilde{x}_{i j}^{2}+\ldots+\tilde{x}_{i j}^{k}\right]
$$

Where $\tilde{x}_{i j}^{K}$ is the ranking of alternative $\mathrm{A}_{\mathrm{i}}$ for criterion $\mathrm{C}_{\mathrm{j}}$ evaluated by the decision-maker of $\mathrm{K}_{\mathrm{th}}$ and $\tilde{x}_{i j}^{K}=\left(a_{i j}^{K}, b_{i j}^{K}\right.$, $\left.c_{i j}^{K}\right)$. The aggregated fuzzy weights are calculated as

$$
\widetilde{w}_{j}=\frac{1}{K}\left[w_{j}^{1}+\widetilde{w}_{j}^{2}+\ldots+\widetilde{w}_{j}^{k}\right]
$$

Step 2: Construction of the fuzzy decision matrix The following are the fuzzy decision matrix:

$$
\widetilde{D}=\begin{array}{c|cccc}
\multicolumn{1}{c}{C_{1}} & C_{2} & \ldots & C_{\mathrm{n}} \\
A_{1} & \tilde{x}_{11} & \tilde{x}_{12} & \ldots & \tilde{x}_{1 n} \\
A_{2} & \tilde{x}_{21} & \tilde{x}_{22} & \ldots & \tilde{x}_{2 n} \\
\vdots & \vdots & \vdots & \ddots & \vdots \\
A_{m} & \tilde{x}_{m 1} & \tilde{x}_{m 2} & \ldots & \tilde{x}_{m n}
\end{array}
$$

Step 3: Normalization of the fuzzy decision matrix

$$
\tilde{R}=\left[\tilde{r}_{i j}\right]_{\mathrm{mxn}}{ }^{\prime} i=1,2, \ldots, \mathrm{m} ; \mathrm{j}=1,2, \ldots, \mathrm{n} .
$$

The normalization of fuzzy decision matrix will performed by following formula:

$\tilde{r}_{i j}=\left(\frac{a_{i j}}{c_{j}^{*}}, \frac{b_{i j}}{c_{j}^{*}}, \frac{c_{i j}}{c_{j}^{*}}\right), c_{j}^{*}=\max c_{i j}$

Step 4: The fuzzy normalized decision matrix weightion

The fundamentals of normalized fuzzy decision matrix, $\tilde{r}_{i j}$, are still triangular fuzzy numbers. The fuzzy normalized decision matrix weight, the form of $\tilde{V}$ is show by the following:

$\tilde{V}=\left[\tilde{v}_{i j}\right]_{\min } i=1,2, \ldots, m ; j=1,2, \ldots, n$

Where $\tilde{v}_{i j}=\tilde{r}_{i j} \otimes \widetilde{w}_{j}$

The elements, $\tilde{v}_{i j}$ are standardized triangular positive numbers and their values range of values at a closed interval $[0,1]$.

Step 5:Determination of the Fuzzy Positive-Ideal (FPIS) and Fuzzy Negative-Ideal (NPIS) solution

$\mathrm{A}^{*}=\left(\tilde{h}_{1}^{*}, \tilde{h}_{2}^{*}, \ldots, \tilde{h}_{n}^{*}\right)$, where $\tilde{h}_{j}^{*}=\max ,\left\{\mathrm{h}_{\mathrm{ij} 3}\right\}$

$\mathrm{A}^{-}=\left(\tilde{h}_{1}^{-}, \tilde{h}_{2}^{-}, \ldots, \tilde{h}_{n}^{-}\right)$, where $\tilde{h}_{j}^{-}=\min ,\left\{\mathrm{h}_{\mathrm{ij} 1}\right\}$ (ii)

Where, $\tilde{h}_{j}^{+}=(1,1,1) ; h_{l}^{-}=(0,0,0), l=1,2, \ldots, \mathrm{n}$.

Step 6: Calculation the distance of between the alternative from FPIS and NPIS

The distance between the alternatives can be calculated as following:

$$
\begin{aligned}
& d_{i}^{*}=\sum_{j}^{n}=\mathrm{d}\left(\tilde{h}_{i j}, \tilde{h}_{j}^{*}\right), i=1,2, \ldots, \mathrm{m} \\
& d_{i}^{-}=\sum_{j}^{n}=\mathrm{d}\left(\tilde{h}_{i j}, \tilde{h}_{j}^{-}\right), i=1,2, \ldots, \mathrm{m}
\end{aligned}
$$

The value $d(.$.$) shows the distance between two triangular$ fuzzy number. The calculation will using Vertex method. Let $\tilde{a}=\left(\tilde{a}_{1}, \tilde{a}_{2}, \tilde{a}_{3}\right)$ with $\tilde{b}=\left(\tilde{b}_{1}, \tilde{b}_{2}, \tilde{b}_{3}\right)$ both are TFNs. The 
Soo-Fen Fam et al., International Journal of Emerging Trends in Engineering Research, 8(9), September 2020, 6397 - 6405

calculation of distance between two numbers are shown in below:

$$
\mathrm{d}(\tilde{a}, \tilde{b})=\sqrt{\frac{1}{3}\left[\left(\tilde{a}_{1}-\tilde{b}_{1}\right)^{2}+\left(\tilde{a}_{2}-\tilde{b}_{2}\right)^{2}+\left(\tilde{a}_{3}-\tilde{b}_{3}\right)^{2}\right]}
$$

Step 7: The closeness coefficients and ranking order of alternatives obtainment

Once the $\mathrm{d}_{i}+$ and $\mathrm{d}_{i}-$ of the alternative are determined, the closeness coefficient of each alternative is obtained. This defines all alternatives ' rating order. The following formula is used to determine the closeness coefficient of each alternative, $\mathrm{CCi}$,

$$
\mathrm{CC} i=\frac{d_{i}^{-}}{d_{i}^{*}+d_{i}^{-}}, i=1,2, \ldots, \mathrm{m} .
$$

$\mathrm{CCi}$ takes its values from 0 to 1 . Alternatives are graded in descending order according to $\mathrm{CCi}$. Instead, with full $\mathrm{CCi}$, we can choose the option. While the $\mathrm{CCi}$ is approaching 1, alternative approaches to FPIS are taking place. On the other hand, while the $\mathrm{CCi}$ is moving away from 1 , alternative approaches to the FNIS are taking place.

\section{ANALYSIS AND RESULTS}

Figure 4 illustrate the flow of data collection and analysis

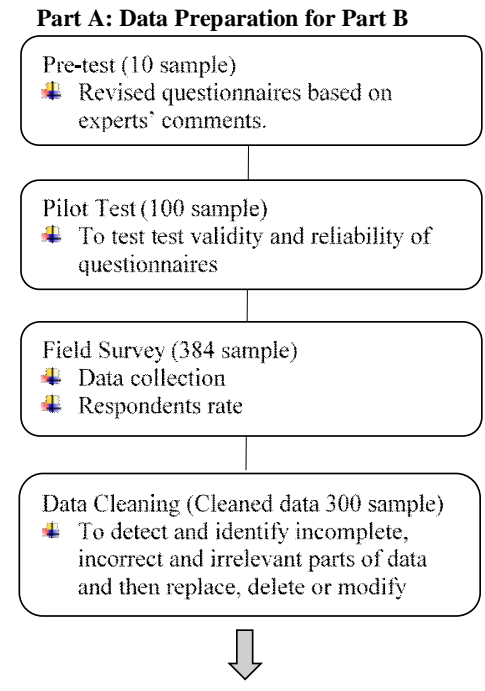

\begin{tabular}{|c|c|c|}
\hline $\begin{array}{l}\text { Summary } \\
\text { transformation of } \\
\text { respondent's answer } \\
\text { data to fuzzy number }\end{array}$ & $\begin{array}{l}\text { Compute the fuzzy } \\
\text { positive and negative } \\
\text { ideal solution }\end{array}$ & $\begin{array}{l}\text { Compute the } \\
\text { distance fuzzy } \\
\text { positive and negative } \\
\text { ideal solution }\end{array}$ \\
\hline $\begin{array}{l}\text { Combined decision } \\
\text { matrix } \\
\text { - Compute the data } \\
\text { from } 300 \\
\text { respondents. }\end{array}$ & $\begin{array}{l}\text { Compute the } \\
\text { weighted nomalized } \\
\text { fuzzy decision } \\
\text { matrix }\end{array}$ & $\begin{array}{l}\text { Compute the } \\
\text { distance for four } \\
\text { attribute from each } \\
\text { critetia. }\end{array}$ \\
\hline $\begin{array}{l}\text { Fuzy criteria } \\
\text { weights based on } \\
\text { responses from } \\
\text { questionnaire. }\end{array}$ & $\begin{array}{l}\text { Compute the } \\
\text { nomalized furzy } \\
\text { decision matrix }\end{array}$ & $\begin{array}{l}\text { Compute the } \\
\text { closeness coefficient } \\
\text { CCi for each } \\
\text { attribute. }\end{array}$ \\
\hline
\end{tabular}

Part B: Fuzzy TOPSIS Analysis

Figure 4.3: Data Analysis Flow Chart
Table 2present Part A results such as the validity dan reliability of questionnaire for pretest, pilot test and field study.

Table 2: Analysis and results for pretest, pilot test and field study.

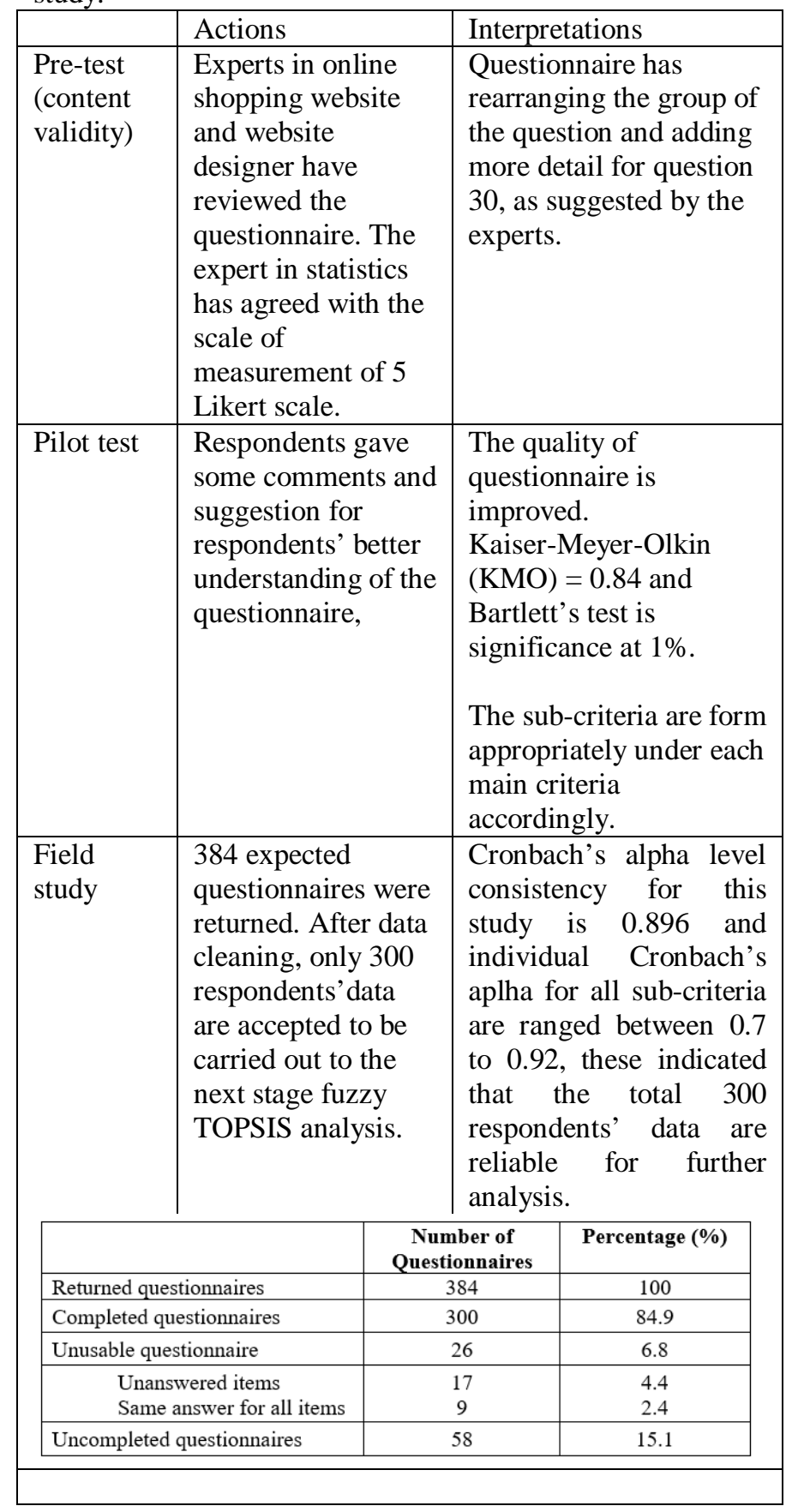

Table 3 present respondents' demographics profile and online shopping behavior with the with the variables, description, frequency and percentage. 
Soo-Fen Fam et al., International Journal of Emerging Trends in Engineering Research, 8(9), September 2020, 6397 - 6405

Table 3: Respondents demographics profile and online shopping behavior

\begin{tabular}{|c|c|c|c|}
\hline Variables & Description & Frequency & Percent (\%) \\
\hline \multirow[t]{2}{*}{ Gender } & Male & 151 & 50.3 \\
\hline & Female & 149 & 49.7 \\
\hline \multirow[t]{6}{*}{ Age } & $15-19$ & 7 & 2.3 \\
\hline & $20-24$ & 45 & 15 \\
\hline & $25-34$ & 75 & 25 \\
\hline & $35-44$ & 70 & 23.3 \\
\hline & $45-49$ & 68 & 22.7 \\
\hline & 50 and above & 35 & 11.7 \\
\hline \multirow[t]{5}{*}{ Ethnicity } & Malay & 124 & 41.3 \\
\hline & Chinese & 105 & 35 \\
\hline & Indian & 53 & 17.7 \\
\hline & Iban/ Kadazan/ Bidayu & 15 & 5 \\
\hline & Expatriate & 3 & 1 \\
\hline Current state during & Johor & 17 & 5.7 \\
\hline \multirow{15}{*}{$\begin{array}{l}\text { Movement Control Order } \\
\text { (MCO) }\end{array}$} & Kedah & 11 & 3.7 \\
\hline & Kelantan & 21 & 7 \\
\hline & Malacca & 37 & 12.3 \\
\hline & Negeri Sembilan & 10 & 3.3 \\
\hline & Pahang & 17 & 5.7 \\
\hline & Penang & 15 & 5 \\
\hline & Perak & 18 & 6 \\
\hline & Perlis & 10 & 3.3 \\
\hline & Sabah & 6 & 2 \\
\hline & Sarawak & 33 & 11 \\
\hline & Selangor & 25 & 8.3 \\
\hline & Terengganu & 10 & 3.3 \\
\hline & Kuala Lumpur & 55 & 18.3 \\
\hline & Labuan & 5 & 1.7 \\
\hline & Putrajaya & 10 & 3.3 \\
\hline \multirow[t]{5}{*}{ Education Level } & No education & 71 & 23.7 \\
\hline & Informal education & 50 & 16.7 \\
\hline & $\begin{array}{l}\text { Primary school equivalent (UPSR, } \\
\text { etc.) }\end{array}$ & 36 & 12 \\
\hline & $\begin{array}{l}\text { Secondary school } \\
\text { (PMR/PT3,SPM STPM) }\end{array}$ & 77 & 25.7 \\
\hline & $\begin{array}{l}\text { University/ College equivalent } \\
\text { (Diploma, Degree, Master, } \\
\text { PhD,etc.) }\end{array}$ & 66 & 22 \\
\hline
\end{tabular}

Continue to the next page... 
Soo-Fen Fam et al., International Journal of Emerging Trends in Engineering Research, 8(9), September 2020, 6397 - 6405

... Continue from the previous page (Table 3)

\begin{tabular}{|c|c|c|c|}
\hline Variables & Description & Frequency & Percent (\%) \\
\hline \multirow[t]{4}{*}{ Marital status } & Single & 86 & 28.7 \\
\hline & Married & 197 & 65.7 \\
\hline & Divorced & 12 & 4 \\
\hline & Widowed & 5 & 1.7 \\
\hline \multirow[t]{4}{*}{ Working status } & Student & 47 & 15.7 \\
\hline & Private sector & 107 & 35.7 \\
\hline & Government sector & 55 & 18.3 \\
\hline & Self-employment & 91 & 30.3 \\
\hline \multirow[t]{5}{*}{ Household Income level } & Below RM3, 000 & 68 & 22.7 \\
\hline & RM3, 001-RM6, 500 & 82 & 27.3 \\
\hline & RM6, 501-RM9, 000 & 117 & 39 \\
\hline & RM9, 001-RM13, 500 & 28 & 9.3 \\
\hline & RM13, 500 and above & 5 & 1.7 \\
\hline \multirow{4}{*}{$\begin{array}{l}\text { The frequency of } \\
\text { respondets visit online } \\
\text { shopping website during } \\
\text { (MCO) }\end{array}$} & Rarely (1-9 time) & 144 & 48 \\
\hline & Sometimes (10-20 time) & 121 & 40.3 \\
\hline & Often (21-100 time) & 29 & 9.7 \\
\hline & Very often (>100 time) & 6 & 2 \\
\hline \multirow{4}{*}{$\begin{array}{l}\text { The online shopping } \\
\text { website that respondents } \\
\text { visited the most }\end{array}$} & Shopee & 118 & 39.3 \\
\hline & Lazada & 88 & 29.3 \\
\hline & Lelong & 51 & 17 \\
\hline & 11-Street & 43 & 14.3 \\
\hline \multirow{12}{*}{$\begin{array}{l}\text { Items bought from online } \\
\text { shopping website/s. }\end{array}$} & Groceries & 96 & 32 \\
\hline & Mobile/ Tablet/ Gadgets & 128 & 42.7 \\
\hline & Computer \& Accessories & 92 & 30.7 \\
\hline & Online games & 32 & 10.7 \\
\hline & Board games/ books & 47 & 15.7 \\
\hline & Sports \& Fitness & 77 & 25.7 \\
\hline & Clothing and accessories & 199 & 66.3 \\
\hline & Home and living & 150 & 50 \\
\hline & Baby\& Toys & 40 & 13.3 \\
\hline & Health \& Beauty & 87 & 34.7 \\
\hline & $\begin{array}{l}\text { Pandemic prevention item (Mask, } \\
\text { Sanitizer, Gloves, etc.) }\end{array}$ & 104 & 34.7 \\
\hline & Miniature & 1 & 0.3 \\
\hline \multirow{3}{*}{$\begin{array}{l}\text { Preferable payment } \\
\text { method }\end{array}$} & Online banking & 250 & 83.3 \\
\hline & Credit/ Debit card & 28 & 9.3 \\
\hline & ATM/ Cash deposit & 22 & 7.3 \\
\hline
\end{tabular}


Soo-Fen Fam et al., International Journal of Emerging Trends in Engineering Research, 8(9), September 2020, 6397 - 6405

Part B is the fuzzy TOPSIS analysis and results which give the final outcomes of this research. The results were shown in Table 4.

Table 4: Fuzzy TOPSIS results

\begin{tabular}{|l|l|l|l|c|}
\hline Alternative & $\mathrm{di}^{+}$ & $\mathrm{di}^{-}$ & $\mathrm{CCi}$ & Rank \\
\hline Lazada & 7.244 & 8.489 & 0.5396 & 2 \\
\hline Shopee & 0 & 11.833 & 1 & 1 \\
\hline 11-street & 11.887 & 2.715 & 0.1859 & 4 \\
\hline Lelong & 12.28 & 4.196 & 0.2547 & 3 \\
\hline
\end{tabular}

By comparing the CCi values of the four alternatives in Table 4 , it is crystal cleared thatShopee online shopping websiteis ranked the first, next is Lazada, then Lelong and finally the 11 -street. The attribute ofShopee is chosen as the best Malaysia online shopping website quality by the 300 online shoppers during the COVID-19 MCO lockdown period.

\section{CONCLUSION AND FUTURE RESEARCH DIRECTION}

Online business plays a significant role in contributing to the Malaysia Sustainable Development Goals, especially goals 8 , which to promote sustained, inclusive and sustainable economic growth and decent work for all. In addition, the Malaysia Sustainable Development Goals 2017 highlights 17 critical aspects of the nation that will guide and lead to a sustainable future. Each aspect represents a goal to be achieved in order to attain Malaysia's vision of becoming a developed nation [39]. The National eCommerce Council $(\mathrm{NeCC})$, consisting of numerous agencies and authorities, was formed to a USD 53 billion GDP contribution by 2020 [38].

. Thus, online businesses needto be a way of assessing their websites continuously to achieve sustainable growth. This study has identified three main criteria and ten sub criteria as the measurable based line for Malaysia online shopping website quality. In addition, this study also has successfully transformed the linguistic variables evaluation to fuzzy TOPSIS measurement where this technique is suitable for subjective analysis.

From the knowledge of authors, this research is the pioneer (first been carried out) for evaluating the quality of online websites in Malaysia by using Fuzzy Topsis method. A similar analysis can, therefore, be mimicked and discussed in other ways. The findings of this analysis can be compared to the results of other fuzzy MCDM approaches such as AHP, VIKOR, ELECTRE and PROMETHEE for further studies. By comparison between the fuzzy MCDM method can determine the differences in their calculation in evaluating the website quality. Successful website quality improvement will offer potential benefits to online shopping vendors and promote online shopping in Malaysia by enhancing the efficiency of the website and growing Malaysia's GDP.

\section{ACKNOWLEDGMENT}

The authors are grateful to SuITE research group for the guidance, thankful to CRIM for the financial support and UniversitiTeknikal Malaysia Melaka for providing the facilities in this study.

\section{REFERENCES}

1. L. Zumba. Covid-19: Online shopping won't get you hard-to-find items during coronavirus pandemic [Internet]. The Star Online. 2020 [cited 2020 Apr 20].Available

from:https://www.thestar.com.my/tech/technews/2020/0 3/31/covid-19-online-shopping-wont-etyou-hard-to-find -items-during-coronavirus

2. S. Saeed, M. Naqvi and M. Memon. E-Commerce Web Crawling to Facilitate Consumers for Economical Choices.Int J Adv ComputSystSoftw Eng.;1(1):1-13. 2020

3. S. Davis, and L. Toney. (2020, March 12). How Coronavirus (COVID-19) Is Impacting Ecommerce https://www.roirevolution.com/blog/2020/08/coronaviru s-and-ecommerce/. Retrieved from ROIREVOLUTION: [August 2020].

4. J.J. Song, S. Baker, Lee and J. C. Wetherbe. Examining Online Consumers' Behavior: A Service-Oriented View. International Journal of Information Management 32: 221-231. 2012.

5. P. Rita,T.Oliveira, andA.Farisa. The Impact of E-Service Quality And Customer Satisfaction On Customer Behavior In Online Shopping.Heliyon v.5(10), 1-14. 2019.

6. A.O. Kalu,A. Anyanwu and J.C. Onwumere. Influence of Website Quality Dimensions on Repurchase Intention: Empirical Evidence From Customers of Jumia Online Stores in Port Harcourt, Rivers State. $\boldsymbol{R S U}$. Journal of Strategic and Internet Business Vol 4, Issue 1, 514-529. 2019.

7. M. Blut.E-service quality: development of a hierarchical model. J. Retail. 92(4):500-517. 2016.

8. Z. Sinuany-Stern, A Mehrez and Y Hadad.An AHP/DEA Methodology for Ranking Decision Making Units. International Transactions in Operational Research 7: 109-124. 2000.

9. R.E. Bellman and L.A.Zadeh.Decision-Making in a Fuzzy Environment.Management Science, Vol 17, No 4. 1970

10. N. F.Özkan1 and Yavuz, F. G. Using Fuzzy Topsis And Regression Based Weights To Rank E-Commerce Websites.Journal of Engineering and Architecture Faculty of Eskisehir Osmangazi University, P. 116 - 124. 2019

11. K. Anshu, L. Gaur, and D. Khazanchi.Evaluating Satisfaction Level of Grocery E-Retailers Using Intuitionistic Fuzzy TOPSIS and ECCSI Model.International Conference on Infocom Technologies and Unmanned Systems, 276-284. 2017

12. N.Alptekin, E.E. Hall and N. Sevim.Evaluation of Websites Quality Using Fuzzy TOPSIS Method.International Journal of Academic Research in Business and Social Sciences, 221-242. 2015

13. W.H. Delone and E. R. Mclean. (2004). Measuring e-commerce Success: Applying the Delone\& McLean Information Systems Success Model. International Journal of Electronic Commerce 9 (1): 31-47, 2004. 
Soo-Fen Fam et al., International Journal of Emerging Trends in Engineering Research, 8(9), September 2020, 6397 - 6405

14. M.H. Hsu, C. M. Chang, K. K. Chu and Y. J. Lee. Determinants of Repurchase Intention in Online Group buying: The Perspectives of DeLone \& McLean IS Success Model and Trust. Computers in Human Behavior 36: 234-245, 2014.

15. J.I. Shin, K. H. Chung, J. S. Oh and C. L. Lee. The Effect of Site Quality on Repurchase Intention in Internet Shopping Through Mediating Variables: the Case of University Students in South Korea. International Journal of Information Management 33: 453-463, 2013.

16. E.T. Loiacono, R. T. Watson and D. L.Goodhue. WebQual: A Measure of Website Quality. Marketing Theory and Applications 13 (3): 432-438, 2002.

17. X. Chen, Q. Huang, R. M. Davison and Z. Hua. What Drives Trust Transfer? The Moderating Roles of Seller- Specific and General. Institutional Mechanisms. International Journal of Electronic Commerce 20 (2): 261-289, 2015.

18. Y.Y. Tan.,S.F. Fam, M.F. Kamarudin, S.I. Wahjono, O.B. Zian.Measuring urban tourist spillover effect toward rural area.International Journal of Recent Technology and Engineering. 8 (2) special issue 11, 701-705, 2019.

19. H.H. Cheng, and S. W. Huang. Exploring Antecedents and Consequence of Online Group-buying Intention: An Extended Perspective on Theory of Planned Behavior. International Journal of Information Management 33 (1): 185-198, 2013.

20. J.W. Siah, and S.F. Fam. Does service quality of self-checkout technology improve purchasing intention in Malaysia retail industry?.International Journal of Engineering and Technology(UAE). 7 (2): 260-264, 2018.

21. H, Zhang, Y. Lu, S. Gupta and P. Gao. Understanding Group-buying Websites Continuance: An Extension of Expectation Confirmation Model. Internet Research 25 (5): 767-793, 2015.

22. H. Kim, and L. S. Niehm. The Impact of Website Quality on Information Quality, Value, and Loyalty Intentions in Apparel Retailing. Journal of Interactive Marketing 23 (3): 221-233, 2009.

23. J.W. Siah, and S.F. Fam, Service quality of self-checkout technology in Malaysian retail industry.International Journal of Recent Technology and Engineering, Vol 8, Issue 1, Pages 179-184. June 2019.

24. Y.K. Zheng, Zhao and A. Stylianou. The Impacts of Information Quality and System Quality on Users Continuance Intention in Information-exchange Virtual Communities: An Empirical Investigation. Decision Support Systems 56: 513-524, 2013.

25. T. Zhou. An Empirical Examination of Continuance Intention of Mobile Payment Services. Decision Support Systems 54 (2): 1085-1091, 2013.

26. Mona et al., (2013). Linking Trust, Perceived Website Quality, Privacy Protection, Gender and Online Purchase Intentions IOSR. Journal of Business and Management (IOSR-JBM), 13(4), 63-72, 2013.

27. H.K. Hasanov.The Impact of Website Quality on Online Purchase Intentionof Organic Food in
Malaysia: A WebQual Model Approach.Procedia Computer Science 72, 382-389, 2015.

28. N. Azureen et.al. Attributable E-commerce toward Purchase Intention: Online Search of Food Product.The SIJ Transactions on Industrial, Financial \& Business Management (IFBM), 2(3), 128-134, 2014.

29. J. Ganesh, K.E. Reynolds, M. Luckett and N. Pomirleanu,.Online ShopperMotivations, And E-Store Attributes: An Examination of Online Patronage Behavior and Shopper Typologies.Journal of Retailing, 86(1), 106-115, 2010.

30. S. Mansori, B. L. Cheng and H.S. Lee. A Study of EShopping Intention in Malaysia: The Influence of Generation $\mathbf{X} \&$ Y.Australian Journal of Basic and Applied Sciences, 6(8), 28-35, 2012.

31. S. Kim and C. Jones. Online shopping and moderating role of offline brand trust. Direct Marketing: An International Journal, 3(4), 282-300, 2009

32. K.C. Tan, M. Xie and Y.N. Li. A Service Quality Framework for Web-Based Information Systems.The TQM Magazine, 15(3), pp.164-172, 2003.

33. D.M. Tuan, T.V.Nikolaevich , N.H. Long, N.V.T. Hiep, N.Q. Dam. A Method of detecting web attacks using behavioral profile analysis technique. International Journal of Emerging Trends in Engineering Research.8(7), 3265-3270, 2020

34. S.J. Barnes and R. Vidgen, 2003. Measuring Web Site Quality Improvements: A Case Study of the Forum on Strategic Management Knowledge Exchange. Industrial Management \& Data Systems, 103(5), pp.297-309, 2003.

35. B. Yoo andN. Donthu.Developing a Scale to Measure the Perceived Quality of an Internet Shopping Site (SITEQUAL). Quarterly Journal of Electronic Commerce, 2(1), pp.31-47. 2001

36. V.A. Zeithaml, A. Parasuraman, and A. Malhotra. Service Quality Delivery through Web Sites: A Critical Review of Extant Knowledge. Journal of the Academy of Marketing Science, 30(4), pp.362-375, 2002.

37. C. Liao, P. Palvia, and J. L.Chen (2009), Information Technology Adoption Behavior Life Cycle: Toward a Technology Continuance Theory, International Journal of Information Management, (29), 309-320, 2009.

38. R. V. Krejcie and D.M. Morgan, (1970). Determining Sample Size For Research Activities. Educational And Psychological Measurement, 607-610. 1970.

39. M.c.Guide, Malaysia - eCommerce. Retrieved from SelectUSA:

https://www.selectusa.gov/article?id=Malaysia-E-Comm erce. (2019, August 8) 